Research.

\title{
THE EFFECT OF ECRI, NPF AND BI RATE UPON MARGIN REVENUE OF MURABAHAH AT BMT ALGHAZALY YEAR 2012 - 2016
}

\author{
Rizki Ahmad Fauzi \\ Lecturer at STIE Binaniaga, Bogor
}

\begin{abstract}
The main task of finance institutions is to collect and distribute the financing and Baitul Mal Tamwil or BMT is one of the financing institutions that is collecting the financing from the clients' capital and savings. Financing distribution is to give the debtors the loan. Most financing support given is Murabahah .

Murabahah is a financial support given thru a trading principle where handing over the ownership has happened. The profit is calculated in advance and as a part of the price of the goods sold.

Determining the profit rate of murabahah financing support has been influenced by many factors. But, the writer is going to pick three factors only, they are an Expected Competitive Return For Investor (ECRI), Non Performing Financing (NPF) and Bank of Indonesia (BI) rate.

Logically, BMT board of directors should have to determine the amount of selling price of murabahah financing support which is based on ECRI and BMT should have given a certain amount which is the remaining of the business revenue to the investor.

However, a risk cost has to be anticipated supposing the debtors cannot afford to pay their loans. And the third variable is $B I$ rate as a considerate reference to evaluate whether the profit of murabahah financing support is competitive in the market or not.
\end{abstract}

Ensuring whether ECRI, NPF and BI rate have been affecting murabahah revenue or not, the writer has applied quantitative method and primary data from the direct key persons.

The result of the research has identified that simultaneously the Expected Competitive Customer Return for Investor (ECRI), Non Performing Financing (NPF)) and Bank Indonesia Rate (BI Rate) have not significantly affected the margin of murabahah revenue at BMT Al Ghazaly refers to its yearly financial report during the years of 2012 up to 2016.

Partially ECRI has not significantly affected the margin of murabahah revenue. Nevertheless, at the same condition, partial NPF has not significantly affected the margin of murabahah revenue. As well as partial BI rate has not significantly affected the margin of murabahah revenue.

Keywords: ECRI, NPF, BI Rate, Margin Revenue, Murabahah

\section{INTRODUCTION}

Baitul Mal Tamwil (BMT) is a kind of syariah bank having small coverage. However, mostly BMT is only a legal cooperation business unit. Nevertheless, its business is just the same with syariah bank providing 'wadiah'contract and 'mudharabah to collect the financing and to perform the murabahah contract as well as to distribute the financing support. Therefore, BMT study is identical to the study of syariah bank.

Refering to Acts No. 21 year of 2008 regarding Syariah Banking Chapter 4, it explains that syariah bank has running its function to collect the financing from the society and to distribute it to the customers. Financing collection has been done

Rizki Ahmad Fauzi: The Effect of ECRI, NPF and BI Rate Upon Margin Revenue

of Murabahah at BMT Alghazaly Year 2012 - 2016 
according to 'wadiah' and mudharabah contract which is the savings, giro and mudharabah deposit, and financing supports / loan distribution that has applied trading principles (murabahah, salam, istishna), revenue sharing principles(mudharabah, musyarakah) and renting principles (ijarah).

Practically BMT activities at Koppontren Al Ghazali (furthermore, it is named BMT Al Ghazali) has provided financing loan to the customer mostly using murabahah method instead of mudharabah.

But, Ascaya (2006:48) has described that "Syariah bank contract is the most important one that should have to be approved by Moslem Religious Leader refers to mudharabah (trustee profit sharing) and musyawarah (joint venture profit sharing). The principle is 'al-ghunm bi'l-ghurn of alkharaj b'il-daman which is not any sharing profit conducted without being involved at any risk (Al-Omar and Abdel-Haq, 1996), or there is not any real economics profit happened without having any real economics costs (Khan, 1995)"

Some considerations have been taken by the writer refers to why BMT Al Ghazali has been distributing more finance support using murabahah method, because (a) It is easier to calculate and monitor it instead of using mudharabah method. In this case, the financing officer should have done much more monitoring, controlling and analyzing the financial statement report issued by the debtor of BMT Al Ghazali. (b) Using Mudharabah method, the main factor is that the debtor should have to be able to create the financial report. However, the debtors who are from mid and small business classes are depending on the competency of the owners of the business whether they are able to prepare their finanvial report or not. Nevertheless, the owners of the business should have been improving their business instead of spending much time just preparing a good administration matters. (c) However, applying murabahah method has made the business' risk relatively smaller and has given relatively a fixed margin instead of applying mudharabah method.

The factor that has been considered to decide the margin is the Expected Competitive Return For Investor (ECRI) (Karim, 2007.280). ECRI is the target of revenue sharing competitively which is expected to be given to the third party. Besides of the aforementioned factor, BMT AL GHAZALY is concerned about the risk related to the financing provided that would happen. One of the risks is customer' default which is the level of Non Performing Financing (NPF). NPF has caused a potential small revenue, since bank will allocate the financing reserve for the Productive Assets Elimination Reserves (PPAP). Therefore, a bank needs to reserve a certain percentage of financing to anticipate such a risk of the credit that would happen (Kasmir, 2008:136).

Practically, one factor that has been applied by BMT AL GHAZALY to identify a margin level is bank interest refers to $\mathrm{BI}$ rate. It should have to be done in order to be able to compete with Syariah Banks or other BMT or conventional banks since Islami bank interest policy has not been available yet. This condition is the main focus of BMT AL GHAZALLY to use the related index bank interest to determine a mark up level (Naja, 2011.82).

Based on the important role of murabahah in providing the biggest revenue for BMT AL GHAZALY, a further analysis is required to define whether the aformentioned factors have affected murabahah margin revenue. Therefore, the writer has chosen the title "THE EFFECTS OF ECRI, NPF AND BI RATE UPON THE MARGIN OF MURABAHAH REVENUE AT BMT AL GHAZALY WITHIN 2012 - 2016"

\section{The Objectives of the Research}

The objectives are expected as follows;

1. Is able to describe a simultaneous effects of the variables ECRI, NPF and BI rate upon the margin of murabahah revenue at BMT AL GHAZALY. 
2. Is able to describe a partial effect of the variables ECRI, NPF and BI rate upon the margin of murabahah revenue at BMT AL GHAZALY.

\section{LIBRARY REVIEW}

\section{A. Murabahah definition}

According to Ascarya (2007:164) in his book Akad and Product of Bank Syariah, murabahah is products selling done by someone to another party which is the seller is obliged to define the cost of goods and margin of the revenue which are calculated in the selling price of the related product, terms of payment which can be executed by cash or credit term."

According to Karim (2007:113), murabahah is a product trading contract mentioning the price and margin revenue agreed by the seller and the buyer. But, Wiroso (2005:13) describing that

Murabahah is the cost of goods sold which has been calculated according to the cost of goods plus mark up or margin of the revenue. Characteristics of murabahah is that the seller should have to inform the buyer about the cost of goods sold plus profit margin". '

In compliance with the aforementioned description, murabahah is a trading of the goods which has described transparently about the cost of goods and margin of the revenue which has been agreed by both parties.

1. Murabahah Scheme

A simple murabahah scheme is described as follows;

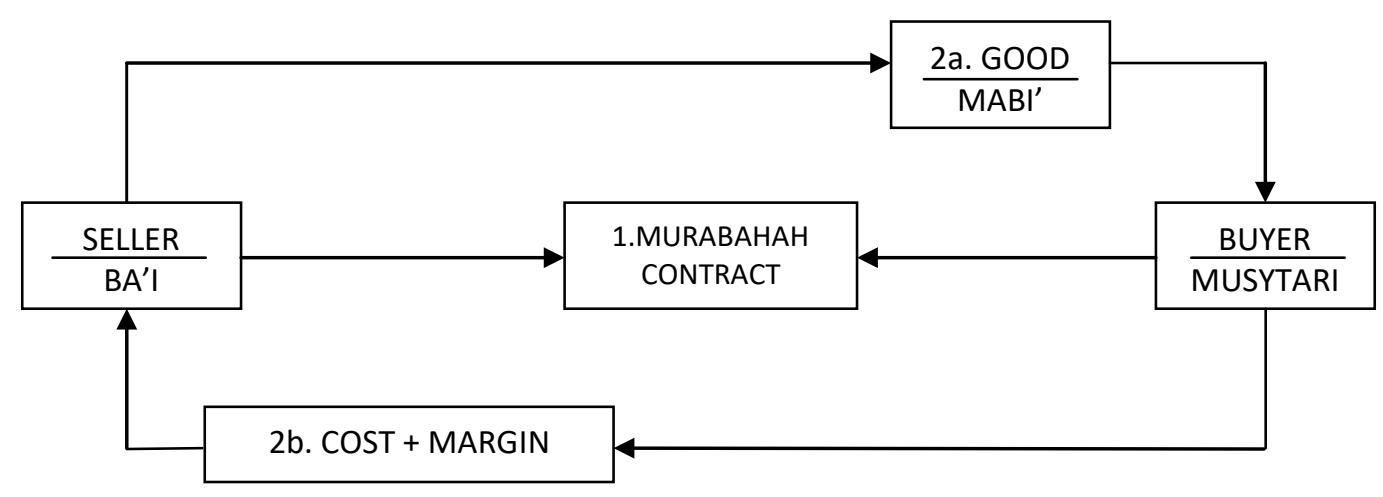

Drawing 1

Scheme of Murabahah Financing

Source: Ascarya, Contract and Product of Bank Syariah (2006:84)

Referring to the aforementioned financing, bank as the financing owner has purchased the goods which is in compliance with the specification required by the clients who need the financial support and has sold it to the related clients including a fixed revenue. However, the clients will return their debts by cash or credit term.

\section{Defining margin of the revenue}

Karim (2007:279-281) has described that Syariah Banks have applied margin of the revenue of the products that have been financed based on the Natural Certainty Contracts (NCC) which is a business contract that has given a

Rizki Ahmad Fauzi: The Effect of ECRI, NPF and BI Rate Upon Margin Revenue of Murabahah at BMT Alghazaly Year 2012 - 2016 
certainty of terms of payment either the amount or the time such as financing of murabahah, ijarah, ijarah muntahia bit tamlik, salam and istishna'.

Technically a margin of the revenue is a percentage calculation on daily base refers to a yearly base which has defined 360 days; when the calculation of the revenue margin is based on a monthly base refers to 12 months / year.

Muhammad (2005:137-138) has declared that it is not any syariah definition occupied related to the business profit margin, however when it has been higher than the related amount it would consider 'haram' (forbidden). Nevertheless, it has been defined as a common norm refers to all kind of trading goods at any time and place. Such a norm has given the advantages as follows;

a. Price differences, sometimes prices differences have happened either very quick or slow. Actually, when they had been quite fast, then the profit would be small. However, when they had been quite slow, then the profit would be huge.

b. The differences between cash payment and credit payment. The profit due to cash payment is smaller than a credit payment.

c. The differences of primary commodity and secondary one. Primary commodity has given a smaller profit than the secondary one since the price of primary one should have to be adjusted with the poor people and other people who need it. However, the luxurious commodity has provided better profit since the price could be determined accordingly.

As it has been described before, there is not any 'sunnah Nabi' defining the profit limitation, so that it is not allowed to get more profit over an acceptable one. However, a hadits has determined that the profit could be double or more at a certain condition.

It has been told by Ahmad in his 'Musnad' from Urwah, as the following The prophet has ever been offered a goat to buy. He has given one dinar to me. The Prophet said, "Hi Urwah, please go to the person who sells that goat, please buy one goat for me". I went to the seller and bargained the price of a goat. Finally I got two goats. I went home with two goats. In another story taking the two goats. On the way home, I met a man and wanted to buy my goats. I sold one goat one dinar. I went back to the Prophet by taking one dinar and one goat. I told the Prophet" Hail the Rasulullah! Here are your goat and your one dinar!' He asked me, "What have you been doing?" I told Him all the story. He said," Ya Allah, bless his profit.' I had more experiences after all, once I had ever standing at Kinasah in Kufah City, I had gained 40.000 dinar profit before I arrived at home to meet my family."

The aforementioned story had told us that it was not cheating, manipulation, monopoli, taking advantage of honest buyer and he increased the price. On the other hand, all this happenings have not figured out a common law of measuring the profit. But the trader has provided an easier way to buy the product which is politeness, satisfaction with small revenue referring to the Syariah spirit and Muslim Leaders teaching.

According to Muljono (2001), some factors that should have to be paid attention moreover in determining the margin, as follows:

a. Profit for the clients, since the competitive market condition has been happening, the price is determined according to the agreement between the buyer and the seller. The buyers have the right completely to define the price and the service of the finance institution determining the best margin of the product purchased.

b. To get more clients achieving the target, the price or margin is an important factor to attract the attention of the potential clients. 
c. Quality of the service, a client is eager to pay the margin as long as his or her credit application is accepted immediately.

d. Potential risk that will be encountered by the businesspeople, it should have relied on the finance institution determining a margin. The smallest the risk, the lowest profit margin will be, and the highest the risk, the biggest profit margin will be.

\section{B. Expected Competitive Return For Investor (ECRI)}

Expected Comptetitive Return For Investor (ECRI) is the target to share an expected competitive revenue given to the third party. Wiroso (2005:89) indicated that a revenue sharing to the third party is a certain portion of revenue sharing given by Syariah Bank to the depositor as the result of the financing management which is coming from the third party. The amount of the revenue sharing has been published according to the equivalent rate.

Equavalent rate is an indicated level of the percentage of revenue sharing received by the clients(based on the calculation of revenue sharing according to the syariah policy). Example, when the net profit of BMT is Rp 10.000 .000 (ten million rupiahs), and according to the Yearly General Meeting, the investor will get 50\%, so that the investor will receive $\mathrm{Rp} \mathrm{5.000.000.} \mathrm{Then} \mathrm{total} \mathrm{of} \mathrm{the} \mathrm{capital} \mathrm{which} \mathrm{is} \mathrm{the}$ obligation saving and special saving amounting to Rp 100.000.000 (a hundred million rupiah) and ECRI is Rp 5.000.000 / Rp 100.000.000 x 100\% = $5 \%$.

\section{The Definition of Non Performing Financing (NPF)}

Daily operational BMT has been encountered various risks related to its function as an intermediary financing support. One of the risks is the client default or clients cannot pay the contract with BMT. Client default has caused a non performing financing. According to Mudrajat and Suharjono (2002:462), non performing financing is a condition when the client is unable to pay partly or all his debts to BMT as agreed. Muhammad (2005:87) has defined NPF as follows;

\section{$\frac{\text { NonPerforming financing }}{\text { Total amount of financing }} \mathrm{x}$}

Category of credit collectability has three parts, as follows;

1. Non performing payment

Is a credit payment that has not been paid for three months over the due date of the payment.

2. Non reliable credit

Is a credit payment that has not been paid for 6 months over the due date of the payment.

3. Unpaid credit

Is a credit payment that has not been paid for more than a year over the due date of the payment.

\section{BI Rate Definition}

BI Rate is a monthly bank interest announced by the Bank of Indonesia periodically for a certain time as a stance or signal of monetary policy (Puspopranoto, 2004:60). However, according to the dictionary of Bank Indonesia, BI Rate is bank interest rate policy to figure out a stance of monetary policy that has been stipulated by Bank Indonesia and announced to the public. Therefore, it can be concluded that $\mathrm{BI}$ Rate is a bank interest rate as a guideline of bank interest applied by the banks and financial authorities in Indonesia

BI Rate is announced by the Board of Governors of Bank Indonesia in their monthly meeting and to be implemented in the operational monetary done Bank

Rizki Ahmad Fauzi: The Effect of ECRI, NPF and BI Rate Upon Margin Revenue of Murabahah at BMT Alghazaly Year 2012 - 2016 
Indonesia refers to the liquidity management at the capital market to reach the target of the operational monetary policy.

The target of the operational monetary policy has been figured out the development of bank interest at the banks capital market overnight (PUAB.O/N). The movement of PUAB interest is expected to be followed by the improvement of deposit interest, and at the end is banking credit interest.

By considering other economics factors, Bank Indonesia will increase $\mathrm{BI}$ rate when it has been over the anticipated target, but on the contrary, Bank Indonesia will decrease $\mathrm{BI}$ rate when the inflation is predicted below the target.

\section{E. Conceptual Design}

To ease the understanding of research flow and the variables that will be studied by the writer, conceptual design will help the writer to do the research. However, the conceptual design is consisting of the process or the steps of the variables being studied by the writer. The related conceptual design is as follows;

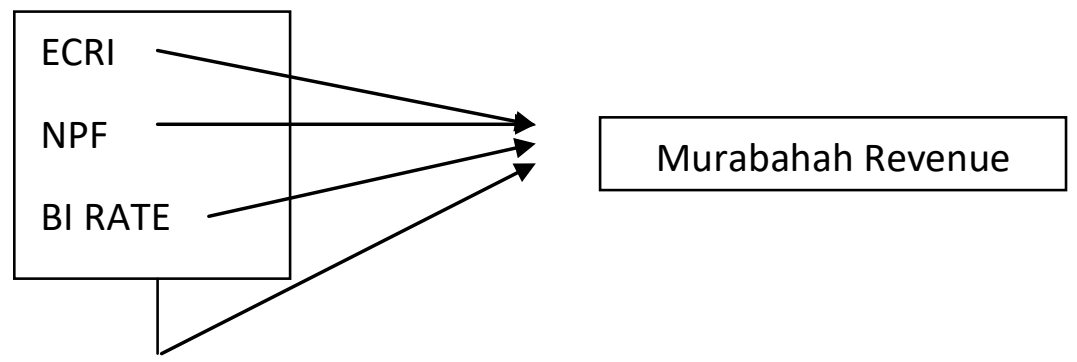

\section{F. Hypothesis of the Research}

A hypothesis is a temporary response upon the research problems which has been identified by thru some questions. Based on the aforementioned design, the following hypotheses are as follows;

1. A significant and simultaneous effect of Expected Competitive Return For Investor (ECRI), Non Performing Financing (NPF). And BI Rate has been occurred upon the margin of murabahah revenue.

2. A significant and partial effect of Expected Competitive Return For Investor (ECRI), Non Performing Financing (NPF) and $\mathrm{BI}$ rate has been occurred upon the margin of murabahah revenue.

\section{RESEARCH METHOD}

\section{A. Research Method}

Research method is a scientifically method to obtain the data for a certain objective and purpose (Sugiyono, 2010:3). Research method has been applied quantitatively since the research data are numeral and the analysis has applied the statistics. Data sampling technique has applied primary data which is the peole have given the data directly to the collector.

\section{B. Operationalizing the Research Variables}

The description of applied variables are as follows;

Rizki Ahmad Fauzi: The Effect of ECRI, NPF and BI Rate Upon Margin Revenue of Murabahah at BMT Alghazaly Year 2012 - 2016 
The Accounting Journal of BINANIAGA Vol. 02, No. 02, December 2017

PISSN: $2527-4309$ EISSN: $2580-1481$

Rizki Ahmad Fauzi: The Effect of ECRI, NPF and BI Rate Upon Margin Revenue of Murabahah at BMT Alghazaly Year 2012 - 2016 
Table 1

Operationalizing Research Variables

\begin{tabular}{|c|c|c|c|c|}
\hline Variable & Variable Definition & Indicator & Scale & Source \\
\hline $\begin{array}{c}\text { Independen } \\
\left(\mathrm{X}_{1}\right) \\
\text { ECRI }\end{array}$ & $\begin{array}{l}\text { Target of expected } \\
\text { competitive revenue } \\
\text { sharing that can be } \\
\text { given to the third party } \\
\text { (Karim,2007:280) }\end{array}$ & $\begin{array}{l}\text { The amount is } \\
\text { from the rate of } \\
\text { return (historical } \\
\text { data / period t- } \\
\text { 1) }\end{array}$ & Ratio & $\begin{array}{c}\text { Finance } \\
\text { Report }\end{array}$ \\
\hline $\begin{array}{c}\text { Independen } \\
\left(\mathrm{X}_{2}\right) \\
\text { NPF }\end{array}$ & $\begin{array}{l}\text { A condition where the } \\
\text { clients are unable to } \\
\text { pay either a part or all } \\
\text { amount of their debts } \\
\text { to the bank (Mudrajat } \\
\text { and Suharjono, } \\
2002 \text { L462) }\end{array}$ & $\begin{array}{l}\text { The amount of } \\
\text { Non Performing } \\
\text { Financing } \\
\text { (NPF) }\end{array}$ & Ratio & $\begin{array}{c}\text { Finance } \\
\text { Report }\end{array}$ \\
\hline $\begin{array}{c}\text { Independen } \\
\left(\mathrm{X}_{3}\right) \\
\text { BI Rate }\end{array}$ & $\begin{array}{l}\text { Interest rate is a policy } \\
\text { figuring out the stance } \\
\text { of monetary policy } \\
\text { stipulated by Bank } \\
\text { Indonesia }\end{array}$ & $\begin{array}{c}\text { Bi rate } \\
\text { announced by } \\
\text { Bank Indonesia }\end{array}$ & Ratio & $\begin{array}{c}\text { Finance } \\
\text { Report }\end{array}$ \\
\hline $\begin{array}{l}\text { Murabahan } \\
\text { earnings } \\
\text { margin }\end{array}$ & $\begin{array}{l}\text { Revenue obtained } \\
\text { from the trading } \\
\text { principles which is } \\
\text { murabahah. Refers to } \\
\text { the credit term } \\
\text { murabahah revenue } \\
\text { paid by cash, then an } \\
\text { incoming cash flow } \\
\text { upon margin revenue } \\
\text { occurred (Wiroso, } \\
\text { 2005:189) }\end{array}$ & $\begin{array}{l}\text { The amount of } \\
\text { the revenue } \\
\text { margin of } \\
\text { murabahah }\end{array}$ & Ratio & $\begin{array}{c}\text { Finance } \\
\text { Report }\end{array}$ \\
\hline
\end{tabular}

Source: from various sources, and data are reanalyzed.

\section{Population and Sample of the Research}

According to Sugiyono (2010:117), population is a generalized area consisting of objects / subjects having a certain quality and characteristics defined by the research to study and to conclude furthermore.

Based on the aforementioned definition, population of this research is the Finance Report of BMT Al Ghazali for the period of 2012 to 2016. 


\section{Method of Analysis}

To determine the frequency effect of ECRI, NPF and BI Rate upon the margin of murabahah revenue at BMT Al Ghazaly during the period of 2012 up to 2016, the writer has done a research applying the following analysis method:

\section{Hypothesis test simultaneously (F-test)}

$\mathrm{F}$ test (F-test) is applied to test whether the independent variables have affected simultaneously the dependent variable. The equation offered by Suliyanto (2011:61) to identify $F_{\text {calculated, }}$ as follows:

$$
\mathrm{F}=\frac{\mathrm{R}^{2} /(\mathrm{k}-1)}{\left(1-\mathrm{R}^{2}\right) /(\mathrm{n}-\mathrm{k})} \times 100 \%
$$

Description

$\mathrm{F}=$ Value of $\mathrm{F}_{\text {calculated }}$

$\mathrm{R}^{2}=$ Determinant Coefficient

$\mathrm{k}=$ Total of the variables

$\mathrm{n} \quad=$ Total of the sampling(size of the samples)

Hypothesis formula of this research, as follows:

a. $H_{0}: \beta_{1}=\beta_{2}=\beta_{3}=0$

The independent variables (ECRI, NPF and $\mathrm{BI}$ rate) simulataneously have not affected significantly the independent variable (margin of murabahah revenue)

b. $H_{a}: \beta_{1} \neq \beta_{2} \neq \beta_{3} \neq 0$

The independent variables (ECRI, NPF and BI rate) simultaneously has affected significantly the dependent variable (margin of murabahah revenue)

This test has been done by comparing the value of $\mathrm{F}_{\text {calculated }}$ with $\mathrm{F}_{\text {table. }}$. The decision making has been defined based on the followings;

a. Comparing the value of $F_{\text {calculated }}$ with $F_{\text {table. }}$.

When $F_{\text {calculated }}<F_{\text {table }}, H_{o}$ is accepted and $H_{a}$ is rejected. It explains that simultaneously the independent variables have not significantly affected the dependent variable.

b. When $F_{\text {calculated }}>F_{\text {table }}, H_{o}$ is rejected and $H_{a}$ is accepted, it explains that simultaneously the independent variables have significantly affected the dependent variable.

The value of significant $F$ at the level of $\alpha$ which is applied $(\alpha=5 \%)$

a. When the significance of $\mathrm{F}<0.05, \mathrm{H}_{\mathrm{o}}$ is rejected, it explains that the independent variables simultaneously have affected significantly the dependent variable.

b. When the significance of $\mathrm{F}>0.05, \mathrm{H}_{0}$ is accepted, it explains that the independent variables simultaneously have affected significantly the dependent variable.

\section{Partial Hypothesis Test (t-test)}

T-test to identify the significant level of each effect (individually) of the independent variable upon the dependent variable (Sugiyono, 2010 :235). Hypothesis formula:

a. Ho: $\beta_{1}=0 \mathrm{ECRI}$ has not significantly affected the margin of murabahah revenue.

$\mathrm{Ha}: \beta_{1} \neq 0 \mathrm{ECRI}$ has significantly affected the margin of murabahah revenue. 
b. Ho: $\beta_{2}=0$ NPF has not significantly affected the margin of murabahah revenue.

$\mathrm{Ha}: \beta_{2} \neq 0$ NPF has significantly affected the margin of murabahah revenue

c. $\mathrm{Ho}: \beta_{3}=0 \mathrm{BI}$ rate has not significantly affected the margin of murabahah revenue.

$\mathrm{Ha}: \beta_{3} \neq 0 \mathrm{BI}$ rate has significantly affected the margin of murabahan revenue.

The calculation of the amount value of $t_{\text {calculated }}$ has applied the following equation (Suliyanto, 2011:62):

$$
t_{i}=\frac{b_{j}}{s b_{j}}
$$

\section{Description:}

$t_{i}=$ Value of $t_{\text {calculated }}$

$b_{j}=$ Regression Coefficient

$\mathrm{sb}_{\mathrm{j}}=$ Error of regression coefficient book value.

It has been decided based on the followings;

a. Comparing the value of $t_{\text {calculated }}$ with $t_{\text {table. }}$.

b. When $t_{\text {calculated }}<t_{\text {table }}, H_{o}$ is accepted and $H_{a}$ is rejected, it explains that significantly the independent variables have not affected the dependent variable.

c. When $t_{\text {calculated }}>t_{\text {table }}, H_{o}$ is rejected and $H_{a}$ is accepted, it explains that significantly the independent variables have affected the dependent variable.

A significant value of $t$ at the level of $\alpha$ applied ( $\alpha=5 \%$ )

a. When the significance of $t<0.05$, Ho is rejected, it explains that the independent variables partially have affected significantly the dependent variable.

b. When the significance of $t>0.05, H_{0}$ is accepted, it explains that the independent variables partially have not affected significantly the dependent variable.

\section{ANALYSIS AND DESCRIPTION}

\section{A. ECRI}

Table 2

The average of ECRI at BMT / year during the years of $2012-2016$

\begin{tabular}{|c|c|}
\hline Year & Average $/$ year \\
\hline 2012 & $9,3 \%$ \\
\hline 2013 & $4,12 \%$ \\
\hline 2014 & $7 \%$ \\
\hline 2015 & $5,6 \%$ \\
\hline 2016 & $4,5 \%$ \\
\hline
\end{tabular}

Source : Finance Report of BMT Al Ghazali

Rizki Ahmad Fauzi: The Effect of ECRI, NPF and BI Rate Upon Margin Revenue of Murabahah at BMT Alghazaly Year 2012 - 2016 
B. NPF

Table 3

The average of NPF at BMT Al Ghazali / year during the years of 2012-2016

\begin{tabular}{|c|c|}
\hline Periode & Average $/$ year \\
\hline 2012 & $1,5 \%$ \\
\hline 2013 & $1,6 \%$ \\
\hline 2014 & $2,0 \%$ \\
\hline 2015 & $1,5 \%$ \\
\hline 2016 & $1,7 \%$ \\
\hline
\end{tabular}

Source : Finance Report of BMT Al Ghazali

\section{BI Rate}

Table 4

BI Rate during the years of 2012-2016

\begin{tabular}{|c|c|}
\hline YEAR & BI Rate \\
\hline 2012 & $5,77 \%$ \\
\hline 2013 & $6,48 \%$ \\
\hline 2014 & $7,73 \%$ \\
\hline 2015 & $7,52 \%$ \\
\hline 2016 & $6,02 \%$ \\
\hline
\end{tabular}

Source : Report of Bank Indonesia published, data reanalyzed

\section{The Revenue Margin of Murabahah}

Table 5

Margin of Murabahah Revenue at BMT Al Ghazaly years of 2012-2016

\begin{tabular}{|c|c|}
\hline Year & The margin of Murabahah revenue (Rp) \\
\hline 2012 & 189.897 .965 \\
\hline 2013 & 162.272 .804 \\
\hline 2014 & 130.911 .920 \\
\hline 2015 & 149.246 .942 \\
\hline 2016 & 129.690 .006 \\
\hline
\end{tabular}

\section{E. Result of the Hypothesis of Ftest}

F-test has been used to test whether the variables ECRI, NPF and BI rate simulataneously have affected the variable of the Margin of Murabahah Revenue. Ftest can be identified on the ANOVA Table by comparing the value of $F_{\text {calculated }}$ with $F_{\text {table }}$ refers to the significant value. 
Table 6

Result of F-test

\begin{tabular}{|c|c|c|c|c|c|}
\hline \multicolumn{6}{|c|}{ ANOVA $^{a}$} \\
\hline Model & Sum of Squares & $\mathrm{df}$ & Mean Square & $\mathrm{F}$ & Sig. \\
\hline Regression & 1969912140368020,000 & 3 & 656637380122673,400 & 1,260 &, $561^{\circ}$ \\
\hline 1 Residual & 521080604791066,400 & 1 & 521080604791066,400 & & \\
\hline Total & 2490992745159086,500 & 4 & & & \\
\hline
\end{tabular}

Source : Analyzed by using SPSS

ANOVA table aforementioned has obtained $F_{\text {calculated }}$ of 1.260 . So that, the value of $F_{\text {calculated }}<F_{\text {table }}$ value. F-test can be identified from the significant value of $0.561^{b}>0.05$. Therefore, referring to the $F_{\text {calculated }}>F_{\text {table }}$ and the significant value $>$ $0.05, \mathrm{H}_{\mathrm{o}}$ is accepted and $\mathrm{H}_{\mathrm{a}}$ is rejected. It can be concluded that simultaneously the variables of ECRI, NPF and $\mathrm{BI}$ rate have not significantly affected the revenue margin.

\section{F. Hypothesis Result of T-test}

The hypothesis test partially has been done using two methods which is comparing the value of $t_{\text {calculated }}$ with $t_{\text {table }}$ and its significant value. When the value of $t_{\text {calculated }}>t_{\text {table }}$ or the significant value has indicated each independent value which is below 0.05 , it explains that the independent variables have affected significantly the dependent variable. And the result of t-test as follows;

Table 7

Result of t-test

Coefficients $^{a}$

\begin{tabular}{|c|c|c|c|c|c|c|}
\hline \multirow{2}{*}{\multicolumn{2}{|c|}{ Model }} & \multicolumn{2}{|c|}{ Unstandardized Coefficients } & \multirow{2}{*}{$\begin{array}{c}\begin{array}{c}\text { Standardized } \\
\text { Coefficients }\end{array} \\
\text { Beta }\end{array}$} & \multirow[t]{2}{*}{$\mathrm{t}$} & \multirow[t]{2}{*}{ Sig. } \\
\hline & & B & Std. Error & & & \\
\hline \multirow{4}{*}{1} & (Constant) & 265341841,257 & 112564858,792 & & 2,357 & ,255 \\
\hline & ECRI & 614644115,809 & 545839622,438 &, 519 & 1,126 & ,462 \\
\hline & NPF & $-7019483227,390$ & 6290942335,050 &,- 583 & $-1,116$ & ,465 \\
\hline & BI RATE & $-506151090,569$ & 1490322144,312 &,- 179 &,- 340 & ,792 \\
\hline
\end{tabular}

Based on the aforementioned test result, it explains that:

1. ECRI variable has not affected significantly the revenue margin which is the significant value $(0.462)>0.05$ and the value of $t_{\text {calculated }}(1.126)<t_{\text {table }}(1.987)$. It has indicated that the increasing of ECRI partially has not affected significantly the margin of murabahah revenue.

2. NPF variable has not affected significantly the revenue margin which is referring to the significant value $(0.465)>0.05$ and the value of $t_{\text {calculated }}(-1.116)<t_{\text {table }}$ (1.987). it has indicated that the increasing of NPF partially has not affected significantly the margin of murabahah revenue.

3. BI rate variable has not affected significantly the revenue margin, it is indicated on the significant value $(0.792)>0.05$ and $t_{\text {calculated }}(-0.179)<t_{\text {table }}(1.987)$. It has indicated that the increasing of $\mathrm{BI}$ rate partially has not affected significantly the margin of murabahah revenue.

Rizki Ahmad Fauzi: The Effect of ECRI, NPF and BI Rate Upon Margin Revenue of Murabahah at BMT Alghazaly Year 2012 - 2016 


\section{CONCLUSION AND SUGGESTIONS}

\section{A. Conclusion}

1. Simultaneously the Expected Competitive Customer Return for Investor (ECRI), Non Performing Financing (NPF) and Bank Indonesia rate (BI rate) have not affected significantly the margin of murabahah revenue at BMT Al Ghazaly during the period of finance report 2012 to 2016.

2. Partially ECRI has not affected significantly the margin of murabahah revenue. As well as at the same condition, partially NPF has not affected significantly the margin of murabahah revenue. And BI rate partially has not affected significantly the margin of murabahah revenue.

\section{B. Suggestion}

Furthermore, in the future the management of BMT Al Ghazaly could consider $\mathrm{ECRI}$, NPF or $\mathrm{BI}$ rate to define murabahah margin during the trading transaction happened with the clients or the buyers.

\section{REFERENCE}

Ascarya. 2006. Akad dan Produk Bank Syariah. PT. Raja Grafindo Persada. Jakarta

Antonio, Muhammad Syafi,i. 2001. Bank Syariah dari Teori ke Praktek. PT. Gema Insani Jakarta.

Adiwarman A. Karim. 2007. Bank Islam: Analisis Fiqih dan Keuangan Edisi Ketiga. Jakarta PT. Raja Grafindo Persada

Daeng Naja, H. R. 2011. Akad Banks Syariah. PT. Buku Seru Jakarta

Kasmir. 2002. Bank dan Lembaga Keuangan Lainnya. Edisi Keenam. PT. Raja Grafindo, Jakarta

Mudrajat Kuncoro dan Suhardjono. 2004. Manajemen Perbankan. BPFE Yogyakarta

Muhammad. 2005. Pengantar Akuntansi Syariah. Penerbit : Salemba Empat Jakarta

Muljono, Teguh Pudjo. 2001. Manajemen Bagi Bank Komersil. BPFE Yogyakarta

Puspopranoto, Sawaldjo. 2004. Keuangan Perbankan dan Pasar Keuangan. Cetakan. Pertama. Pustaka LP3ES Jakarta

Sugiyono. 2010. Metode Penelitian Kuantitatif, Kualitatif dan RND. Penerbit : Alfabeta Bandung

Wiroso. 2005. Penghimpun Dana Dan Distribusi Hasil Usaha Bank Syariah. Penerbit: PT. Grasindo Jakarta

Wiyono, Slamet. 2005. Cara Mudah Memahami Akuntansi Perbankan Syariah Berdasarkan PSAK dan PAPSI. PT. Gramedia Widiasarana Indonesia, Jakarta

Rizki Ahmad Fauzi: The Effect of ECRI, NPF and BI Rate Upon Margin Revenue of Murabahah at BMT Alghazaly Year 2012 - 2016 